https://helda.helsinki.fi

\title{
Legal Codes as Cultural Products
}

Pihlajamäki, Heikki

Oxford University Press

2020-04-02

Pihlajamäki , H 2020 , Legal Codes as Cultural Products . in S Stern , M Del Mar \& B Meyler (eds), The Oxford Handbook of Law and Humanities ., 39 , Oxford University Press , pp. 703-718 . https://doi.org/10.1093/oxfordhb/9780190695620.013.37

http://hdl.handle.net/10138/338140

https://doi.org/10.1093/oxfordhb/9780190695620.013.37

unspecified

acceptedVersion

Downloaded from Helda, University of Helsinki institutional repository.

This is an electronic reprint of the original article.

This reprint may differ from the original in pagination and typographic detail.

Please cite the original version. 
Heikki Pihlajamäki

\section{Legal Codes as Cultural Products}

\section{Keywords:}

Codification, legal history, nationalism, France, Sweden, legal modernization, middle ages, nineteenth century, Code Civil, Germanic codes

\section{Abstract:}

Legal codes have served multiple purposes. From early on, they have served as symbols of power, drawing their legitimacy from ancient roots. When observed historically, the practical importance of the codes has often been meagre. Although the symbolic significance of the codes has never disappeared, from the nineteenth century onwards their importance for practical legal life has been undisputable. The traditional view of looking at the codification history through the lenses of nineteenth-century history of continental law is in many ways misleading and in need of revision.

1. Introduction: the traditional approach and its problems

For decades, codifications have been an important topic in international legal historical research. The great codifications such as the Prussian, French, Austrian, and German civil codes have been seen as a central phenomenon of nineteenth-century legal history. This approach, however, is desperately outdated and has little to give for today's legal research - for four reasons.

First, the traditional codification-centered research represents an old-fashioned, nationally oriented approach, which looks at the European and even global development through the lenses of major European states, typically France or Germany. It often either neglects all fringe areas (such as Eastern Europe or the Nordic countries) or gives their histories little or no attention. When these histories differ from those of the major countries, these histories tend to be treated as anomalies or exceptions that do not change the main rule. This is a general problem in much of the traditional legal history. Indeed, questioning the traditional codification history may have fatal consequences for traditional European legal history as a whole. 
Second, the traditional emphasis on the late eighteenth and nineteenth century codification excludes earlier codes, such as the Constitution of Electoral Saxony (1572) and early modern Nordic codes (The Swedish, Danish, and Norwegian Laws of the Realm, of 1734, 1683, and 1686, respectively). ${ }^{1}$ The reason behind the common exclusion is that only the "mature" codifications, supposedly, were based on a scientific system, and meant as comprehensive and exclusive. The Swedish Law of the Realm, however, claimed comprehensiveness and exclusivity as well; on the other hand, nineteenthcentury codes never managed to monopolize the field of legal sources anywhere. Other legal sources - such as legal practice, travaux préparatoires, and scholarship - always came to fill the unavoidable lacunae and interpretative needs.

Furthermore, normativity beyond codifications and written statutes in general merits consideration. Normative ethics - that is, a body of rules developed by theologians - occupied a major role in the whole of normativity in the middle ages and in the early modern period, as Wim Decock has recently demonstrated for contract law. ${ }^{2}$ Paolo Prodi then, has magnificently described the gradual erosion of normative ethics toward the end of the early modern period, and the substitution of ethics for law. ${ }^{3}$ This process created the present situation with hardly any all-encompassing ethical rules. Again, Prodi's story suits well the heartlands of Continental Europe, but less so the Nordic and the Eastern regions. Normative ethics as a clearly defined body of rules never developed in Scandinavia, or was at least replaced by legal norms earlier than in the more southern parts of Europe. In an earlier work, I have described how a Swedish "pre-positivism” emerged this way. ${ }^{4}$

Third, codifications and other forms of normativity are cultural products and need to be viewed in that context as well. The nineteenth-century codification movement, rightly so, has often been linked to nationalism. Codification was now one of the instruments with which national unity was created much like the national flag and the national anthem. This has been the case not only for the French Code Civil, but also just as much for the Italian (1865), German (1900), and Dutch codes (1938). The codes enacted in the new republics born out of the collapse of the Soviet Union, and those of the ex-

\footnotetext{
${ }^{1}$ See, however, Sten Gagnér, Studien zur Ideengeschichte der Gesetzgebung (Stockholm: Almquist \& Wiksell, 1960), who calls the medieval wave of legislation already a "codification movement"; and Mathias Schmoeckel,"Leges et in carmina redigendae sunt: Die Erfindung der Kodifikation als Konzept durch Melanchthon und deren Rezeption in katholischen Staaten bis 1811," Zeitschrift der Savigny-Stiftung für Rechtsgeschichte, Kanonistische Abteilung 126 (2009): 397-43, suggesting that the sixteenth-century Protestant jurists invented the modern idea of codification.

${ }^{2}$ Wim Decock, Theologians and Contract Law: The Moral Transformation of the Ius Commune (ca. 1500-1650) (Leiden: Brill, 2012).

${ }^{3}$ Paolo Prodi, Una storia della giustizia: Dal pluralismo dei fori al moderno dualismo tra coscienza e diritto (Bologna: Il Mulino, 2000).

4 Heikki Pihlajamäki, "Legalism Before the Legality Principle? Royal Statutes and Early Modern Swedish Criminal Law," in From the Judge's Arbitrium to the Legality Principle: Legislation as a Source of Law in Criminal Trial, Georges Martyn, Anthony Musson and Heikki Pihlajamäki (eds.), (Berlin: Duncker \& Humblot, 2013), 169-188.
} 
socialist republics, demonstrate a highly symbolic value for the newly found national unity. However, in the Nordic countries, already the early modern codes fulfilled the function of national symbols, which presumably lessened the need for "modern" codifications. Nationalism could also lead to noncodification. Catalonia is an example of this. Catalonia did not codify its civil code until 1960, preferring to stick to its local customary law with the Spanish civil code as subsidiary law. Instead, the Catalonian customary law became the carrier of nationalistic sentiments. ${ }^{5}$

Fourth, scholars have not given enough attention to European codifications as export products. In the nineteenth and twentieth centuries, the great European codes - the French and German civil codes, most notably - spread to all other continents, Australia excluded. A notable exception from the scholarly lack of interest in this problem is Jean-Louis Halpérin, who has recently explained how the Western concept of law has been exported to other continents, and how, using the Roman law frame, social and customary rules have been transformed into laws. ${ }^{6}$ Codes as the main outcome of continental nineteenth-century legal formalism have often served as a yardstick to measure the legal nature of normative orders of non-European regions as well. Interestingly, however, scholars of customary law have at least since the early 1960s felt uneasy about recording - in fact, codifying African customary laws. ${ }^{7}$ If modern legal history strives for global significance, these questions must receive more attention.

Many see the spread of Western codes as a form of cultural colonization, as Western laws often go together with Western economic influence. Western values are based on individualism, which has its roots in Roman law and the Enlightenment, and individualism easily gets into conflict with Asian and African collective values. This need not, however, be the only interpretation. Western codes also carry with themselves the idea of liberal human rights, which, according to critical voices is a form of cultural colonization as well. ${ }^{8}$ There are, however, other ways of looking at this, as it may also be the case that Asian and Africans feel that they benefit from Western-originated rights and freedoms.

\footnotetext{
${ }^{5}$ Steve Jacobson, "Law and Nationalism in Nineteenth-Century Europe: The Case of Catalonia in Comparative Perspective," Law and History Review 20:2 (2002): 307-347.

${ }^{6}$ Jean-Louis Halpérin, “The Concept of Law: A Western Transplant?”, Theoretical Inquiries in Law 10:2 (2009), 333354.

${ }^{7}$ See William Twining, The Place of Customary Law in the National Legal Systems of East Africa (Chicago: The University of Chicago Law School, 1963).

${ }^{8}$ See, David Kennedy, Dark Sides of Virtue: Reassessing International Humanitarianism (Princeton: Princeton University Press, 2005).
} 
Furthermore, one may question the assumption that Western rights and freedoms are only Western or any more just Western in the first place. ${ }^{9}$

However, the problem is not only about whether Western law colonized other continents. It is also about cultural misrepresentations: looking towards the East and the South through Western lenses. The discussion started with Edward W. Said and his classic idea of "Orientalism," which denotes "subtle and persistent Eurocentric prejudice against Arab-Islamic peoples and their culture." In Said's thinking, Western-created cultural representations of the East portray Asia, Middle East, and North Africa as a fictional, sometimes romanticized "Orient," which dominates the Western discourses on the subject. ${ }^{10}$ Said's Orientalism serves as inspiration to Teemu Ruskola's concept of "Legal Orientalism," which refers to the way European thinkers, starting from giants such as Montesquieu, Hegel, Marx, and Weber, have "affirmed the superiority of Western civilization of law". ${ }^{11}$ Traditionally, the Chinese normative world - as a kind of "non-law" - has been portrayed as the irrational opposite to Europe's rational law. However, it has been shown that this picture tells more about the nineteenth-century European law than Chinese normativity as a whole. It has also been shown that the decision-making at Chinese courts was not "substantially irrational" - as Max Weber claimed - but in fact rather bound by written law - thus, in Weber's terminology, "formally rational." Another example comes from international law, whose traditional histories, created from the 1860s onwards, have been profoundly Euro-centered. ${ }^{12}$

The nineteenth-century European code, then, has been the lens through which much of global history has traditionally been viewed. The concept of codification has enabled legal historians to judge pre-nineteenth-century European legal orders as "not-yet" or "not-really" codified, and the same has applied to those nineteenth-century legal orders, which have not been codified according to the model of the dominant European nations. The model of European nineteenth-century law has helped to place non-European normative orders, such as Far Eastern ones, outside the domain of law and to qualify them as irrational. The idea of codification continues to represent, for many, “true law," which partly explains the attempts, some successful and some failed, to codify law in

\footnotetext{
${ }^{9}$ Steven Pinker, Enlightenment Now: The Case for Reason, Science, Humanism, and Progress (New York: Penguin Books, 2018).

${ }^{10}$ Edward Said, Legal Orientalism (New York: Pantheon, 1978).

${ }^{11}$ Teemu Ruskola, Legal Orientalism: China, the United States, and Modern Law (Cambridge, Mass.; Harvard University Press, 2013).

${ }^{12}$ See Martti Koskenniemi, The Gentle Civilizer of Nations: The Rise and Fall of International Law 1870-1960 (Cambridge: Cambridge University Press, 2001).
} 
different parts of the worlds and on different levels of the pluralist global law. Examples range from the strivings to codify European civil law to "new" lex mercatoria and international law. Capturing the fast-changing law, which appears and emerges in different degrees and modes of normativity (from moral to customary rules and to "hard" legal rules), into a code has often proved difficult and largely lost its popularity. The "creeping codification of the new lex mercatoria," for instance, differs in many ways from traditional codification: it cannot serve as the sole base of decisionmaking in international commercial disputes. ${ }^{13}$

This Chapter addresses these four problems of traditional research and then advances to present the phenomenon in a fuller transnational, cultural context. First, traditional presentations of European legal history culminate in the German nineteenth-century conceptual jurisprudence and its master accomplishment, the Civil Code of 1900. However, the traditional presentations pay little or no attention to the fringe areas of European legal culture, which distorts the view of European legal history (Part II). Part III criticizes the traditional, Weberian conception of codification as the foremost driver and instrument of legal modernization. Part IV, then, questions the traditional way of excluding law codes other classical, nineteenth-century codifications from the concept. Part V discusses the use of legal codes as symbols, and instruments of government and legal practice. Part VI concludes the essential findings and brief presents some new research questions.

\section{The emphasis on European heartlands}

Douglas Osler has talked about "a myth of European legal history." Traditionally, text books of legal history have been based selectively on such pieces, which best support the culmination of European legal history in the glorious nineteenth-century German law and especially German Civil Code of 1900. The selection begins with Roman and Italian legal history, which dominates the scene until the end of the Middle Ages. The emphasis then shifts to Humanism, first in France and then in the Netherlands. After that begins the era of the Historical School and Pandectism, which ultimately leads to the Civil Code. ${ }^{14}$

The traditional codification-centered approach represents an old-fashioned, nationally oriented research, which looks at the European and even global development through the lenses of major

\footnotetext{
${ }^{13}$ See Klaus Peter Berger, The Creeping Codification of the New Lex Mercatoria (London: Springer, 1999).

${ }^{14}$ Douglas Osler, "The Myth of European Legal History", Rechtshistorisches Journal 16 (1997): 393-410-
} 
European states. The traditional story that Osler depicts often either neglects all fringe areas or gives their histories little or no attention. They have no place in the story, which is constructed - and I think Osler is right here - with the German Civil Code of 1900 as its focal point and culmination. The traditional story thus distorts not only the codification history itself, but the whole legal history of the continent. ${ }^{15}$

What are these neglected fringe areas? To start with, the vast regions of Eastern Europe are usually left out of the story. Naturally enough, they do not form one culturally definable area but instead several. Russia, Ukraine, and Belo-Russia form a region, which was relatively little influenced by learned laws - Roman and Canon - until the nineteenth-century. Yet concentrating on the effect of learned laws is precisely the kind of legal history writing, which departs from the standards supporting the Oslerian "myth." Looking at Russian legal history on its own terms, modern research has shown, for instance, that Russian peasant courts of the early modern period, and even the early twentieth century relied on written legal sources to a high degree. ${ }^{16}$ This is a completely different picture that challenges the view that many would intuitively hold of Russia as a kind of "Other" and "completely" different from the West. In this respect, the traditional picture of Russia seems as distorted as Edward Said and Teemu Ruskola have shown the image of China to be. We will return to Russia's complicated nineteenth-century codification history later.

In certain respects, Russian legal history resembles another neglected area, which is Scandinavia, or the Nordic region. ${ }^{17}$ As in Russia, so also in Scandinavia the influence of learned bodies of law was relatively modest all through the early modern period. This does not, however, mean that the Nordic region would have constituted a legal void. Like in Russia, Scandinavian courts relied surprisingly much on written law as a source of law from an early point on. Denmark, Norway, and Sweden all had provincial and (with the exception of Denmark) also realm-wide legislation already in the

\footnotetext{
${ }^{15}$ Examples include traditional presentations of European legal history such as Mario Bellomo, The Common Legal Past of Europe, 1000-1800 (Washington, D. C.: The Catholic University of America Press, 1995) Newer text-books tend to follow the same trend; see e.g. Bart Wouters and Marco de Benito, A History of Law in Europe: An Introduction (Cheltenham: Edwar Elgar, 20187). A recent attempt to remedy this problem is The Oxford Handbook of European Legal History (Oxford: Oxford University Press, 2018), Heikki Pihlajamäki, Markus Dubber \& Mark Godfrey (eds.), which devotes chapters to the histories of fringe areas, such as Scandinavia, Eastern Europe, and the European colonies on different continents.

${ }^{16}$ Nancy Kollman, Crime and Punishment in Early Modern Russia (Cambridge: Cambridge University Press, 2012); and Jane Burbank, Russian Peasants Go to Court: Legal Culture in the Countryside, 1905-1917 (Bloomington: Indiana University Press, 2004).

${ }^{17}$ The terms Nordic region and Scandinavia are, for the sake of simplicity, used here synonymously, comprising Denmark, Finland, Iceland, Norway, and Sweden.
} 
Middle Ages. ${ }^{18}$ In the early modern period, new realm-wide laws were issued in all three countries: the Danish Law (Danske Lov) in 1683, the Norwegian Law (Norske Lov) in 1686, and the Swedish Law of the Realm in $1734 .{ }^{19} \mathrm{I}$ will later return to the question of whether these can be considered codifications.

This is not the place to patch up systematically all the blank spots of traditional European histories. Suffice it to mention that many other areas of Eastern Europe (such as Poland, Hungary, and Croatia) followed the core European ius commune route more closely than the Nordic Region and Russia. $^{20}$ The examples of Russia and Scandinavia are, however, important because they shed a different light on the history of codification and written law. They are, as mentioned above, examples of "pre-positivism." They offer examples of legal orders, which written law dominated surprisingly early. For the history of codification, this is significant.

III. Legal codes and the problem of legal modernization

The centeredness on European heartlands is not the only problem related to legal codes. The second has to do with modernization. Once we get over the hurdle of defining this notoriously difficult concept, the question that needs to be asked is how much did the classical (meaning nineteenth- and twentieth-century) codifications contribute to modernization. How necessary or useful were they, and how did they sometimes perhaps even hinder modernizing processes? If codifications have been crucial to legal and social modernization, how is it possible that such large tracts of the globe (such as the common law world and Scandinavia) have been able to go through these processes perfectly well without codifications? Should be pay attention to different degrees and ways of codifying normative material (field codes, partial codifications, systematization of case law)?

A brief introduction to the concept of modernization is first needed. After the Second World War, a theory of modernity based on Weberian premises became a popular way of understanding social

\footnotetext{
${ }^{18}$ See Mia Korpiola, "High and Late Medieval Scandinavia: Codified Vernacular Law and Learned Legal Influences," in The Oxford Handbook of European Legal History, Heikki Pihlajamäki, Markus Dubber \& Mark Godfrey (eds.), (Oxford: Oxford University Press, 2018), 378-403.

${ }^{19}$ See Heikki Pihlajamäki, "Scandinavian Law in the Early Modern Period," in The Oxford Handbook of European Legal History (Oxford: Oxford University Press, 2018), Heikki Pihlajamäki, Markus Dubber \& Mark Godfrey (eds.), 806-839.

${ }^{20}$ On these, see Mia Korpiola, "Customary Law and the Influence of the Ius Commune in High and Late Medieval East Central Europe," in The Oxford Handbook of European Legal History (Oxford: Oxford University Press, 2018), Heikki Pihlajamäki, Markus Dubber \& Mark Godfrey (eds.), 404-439.
} 
change globally. This traditional understanding of modernization relied heavily on law-related elements such as rational bureaucracy, secularization, legal positivism, the legal profession, the rule of law, industrial capitalism, democracy, and human rights. The assumption seemed to be that this Weberian paradigm could be easily adopted to a broader and more global perspective, as well. After the positive tones of the post-war era, this traditional way of understanding modernization has, however, become less convincing. It is one of the main bêtes noires of critics such as Dipesh Chakrabatry $^{21}$ attacking the concept's Eurocentrism because of its undeniable roots in European history and philosophy. Indeed, the traditional narrative of legal modernization is suspect on two accounts: both as a historical narrative, and as a description of the contemporary world.

As a historical narrative, the traditional understanding of modernization is unconvincing because it automatically assumes a certain connection between elements that supposedly belong together. The ideal type of legal modernity, consisting of components such as rational bureaucracy, secularization, and legal positivism, is historically speaking unrepresentative of global regions other than the European heartland. As Ugo Mattei has shown, modernizing elements may well dominate some parts of a legal order while being completely absent in others. ${ }^{22}$ The legal order may well be to a large extent modern in the traditional sense of the term while the political system is profoundly undemocratic - contemporary Russia being a case in point. On the other hand, many central features of modern law date further back in history than the nineteenth century. Depending on where we place the decisive "revolutions" of law, the crucial ruptures can be found either/and in the late Middle Ages,${ }^{23}$ the Reformation era, ${ }^{24}$ or the formation of the modern state in the seventeenth and eighteenth centuries. ${ }^{25}$ Of course, the Weberian modernization scheme does not take into account post-war transformations such as federative tendencies (of which the European Union is a prime example) or the impact of international law in a globalized world. ${ }^{26}$ Closely linked to the growth of industrial

\footnotetext{
${ }^{21}$ Dipesh Chakrabatry, Provincializing Europe: Postcolonial Thought and Historical Difference (Princeton: Princeton University Press, 2008).

${ }^{22}$ Ugo Mattei, “Three Patterns of Law: Taxonomy and Change in the World's Legal Systems", American Journal of Comparative Law 45:1 (1997): 5-44.

${ }^{23}$ Harold Berman, Law and Revolution: The Formation of the Western Legal Tradition (Cambridge, Mass.: Harvard University Press, 1983).

${ }^{24}$ Harold Berman, Law and Revolution: The Impact of the Protestant Reformations on the Western Legal Tradition Tradition (Cambridge, Mass.: Harvard University Press, 2006).

${ }^{25}$ Jean-Louis Halpérin, Five Legal Revolutions since the 17 $7^{\text {th }}$ Century: An Analysis of a Global Legal History (Cham: Springer 2014).

${ }^{26}$ Halpérin, Five Legal Revolutions.
} 
capitalism in the nineteenth and twentieth centuries, the traditional notion of modernization may offer little help in trying to understand a "post-capitalist," 27 data-driven economy and its systemic demands.

The European and Western bias of the traditional understanding of modernization is obvious: the less we have to do with the industrialized West, the weaker the explanatory power of the traditional Weberian model becomes. The historical narrative of legal modernization, based on continental (especially German) legal history, fails to explain many legal changes at the fringes of the Western world (such as Eastern Europe, the Nordic countries, and Latin America), not to mention Africa and Asia. This is a problem with some recent historical accounts, as well. The relationship between religion and legal modernization is an issue of utmost importance in world politics today, and it requires explanation as countries at very different levels of secularization have, nonetheless, undergone similar extensive legal changes since the late nineteenth century. To quote Teemu Ruskola, "the relationship between [non-Western legal traditions] and modernity cannot be simply a one-sided affair, with the West providing the blueprint for modern legal order and [other parts of the world] merely executing it." As Ruskola shows, Chinese corporate law, for instance, not merely reflects the Western public-private dichotomy, but it also transcends it combining aspects of Confucianism, socialism, and liberalism. ${ }^{28}$

The traditional narrative of modernization is equally flawed as a description of the contemporary legal world. The "postmodern" understanding of law was already a fundamental blow. The postmodern mind had shifted the focus of legal analysis away from modern law understood as a unitary system isolated from other facets of culture and society. Law is, then, fundamentally pluralistic with "minor jurisprudences" as different forms of legal knowledge competing with the traditional modernist notion of a unitary system of law. ${ }^{29}$ The theoretical premises of this pluralistic view of a global legal world were further elaborated by Brian Tamanaha ${ }^{30}$ from a socio-legal perspective, by William Twining ${ }^{31}$ as a renewed understanding of a global jurisprudence, and most lately by Hans Lindahl as a phenomenology of what he calls the "a-legal". ${ }^{32}$

\footnotetext{
${ }^{27}$ Paul Mason, PostCapitalism: A Guide to our Future (London: Allen Lane 2015).

${ }^{28}$ Ruskola, Legal Orientalism.

${ }^{29}$ Sionaidh Douglas-Scott, Law after Modernity (London: Hart Publishing, 2013).

${ }^{30}$ Brian Tamanaha, A General Jurisprudence of Law and Society (Oxford: Oxford University Press, 2002).

${ }^{31}$ William Twining, General Jurisprudence: Understanding Law from a Global Perspective (Cambridge: Cambridge University Press, 2009).

${ }^{32}$ Hans Lindahl, Fault Lines of Globalization: Legal Order and the Politics of A-Legality (Oxford, Oxford University Press 2013).
} 
This narrative is also hopelessly attached to the nation state. It presupposes a legal order that emanates from a nation state and is enforced within its territory while an international legal order would then consist of public international law and the choice-of-law rules of private international law. For the past decades, the traditional picture of modern law has become even less apt to describe law as a global phenomenon. Transnational law in its different guises (new lex mercatoria, international sports law, transnational administrative law, soft law, voluntary standards, etc.) does not fit the traditional description, and even the concept of transnational law itself remains obscure. ${ }^{33}$

At the same time, legal modernization has a political side to it. Arguably, some of the traditional core elements and values of modernization and modern law and society have recently been jeopardized on a massive scale. These include notions such as rational bureaucracy (deregulation frenzy, sidestepping legal processes), secularization (the return of religion on many fronts), legal positivism (governance methods and technologies, regulation with coded architecture), the legal profession (engineers as judges in the Unitary Patent Court, algorithmic decision-making), the rule of law (Russia, Poland, Hungary, the return of geo- and power-politics on the international level), liberal democracy (populism, authoritarianism, anti-EU movements, nationalism, distortion of the networked communications), and human rights (UK, Russia, US, the refugee question in EU countries). Some scholars have argued that in the current political climate and turbulent times, scholarship should defend, adapt to new circumstances, and develop further many of the values of modernization, not tear them apart and participate in denying their meaning and credibility ${ }^{34}$.

However, while the traditional Weberian theory of legal modernization has lost much of its credibility, critics have offered little in exchange. Instead, they have either limited themselves to particular new features of contemporary law (e.g. different forms of transnational law), or, refusing to build "grand theories", explained the prevailing situation as a form of unstructured legal pluralism. Although there are remarkable works on global law from contemporary socio-legal (Tamanaha, Twining) or theoretical perspectives (Lindahl), no single theory has emerged which would help to understand the main features of global legal development in historical perspective at the same time. To remedy this explanatory deficit, what is needed is a theory that would depart from the traditional

\footnotetext{
${ }^{33}$ Roger Cotterrell,"What is Transnational Law," Law \& Social Inquiry 37:2 (2012): 500-524; Transnational Law: Rethinking European Law and Legal Thinking, Miguel Maduro, Kaarlo Tuori, and Suvi Sankari (eds.), (Cambridge, Cambridge University Press 2014).

${ }^{34}$ Seyla Benhabib, Dignity in Adversity: Human Rights in Troubled Times (London: Polity Press, 2011).
} 
premises of the nation state and positive law, but include them in its explanatory apparatus all the same - and do all this in a historically accurate way.

It is now time to link back to codification. Already for Weber himself, the link was obvious. The French Civil Code represented for him the first legislative product, which was both formally and materially rational. In other words, the Civil Code stood at the highest level of development: "As as product of national legislation, the Code Civil has become the third of the world's three great systems of law, alongside Anglo-Saxon law, a product of juristic practice, and the Roman common law, a product of theoretical-literary juristic doctrine. It has also become the foundation of the vast majority of eastern and central European codifications." 35

Following Weber, standard legal historical narratives have taken the nineteenth-century codes as motors of legal modernization. If one were to choose only one legal phenomenon as the symbol of legal modernization, it could well be the civil code. A leading European legal historian recognizes "in the code the road to the modernization of civil law." The code, he claims, brought about "an epochal turn in European legal history. ${ }^{36 "}$ The civil codes, the story goes, contributed to the modernization of private law; in other words, they solved the fundamental antagonism between universally oriented and national legal systems, customary and statutory law, public and private law, non-dispositive and dispositive law, segmented and general legal capacity, and divided and absolute ownership of land. Codifications have been depicted as an important part of the "civilian's contemporary epistemological construct"; part of her or his mentalité. The civilian thus "reasons from the social and legal perspective embodied in the code." However, it is doubtful whether private law codification is such an indispensable part, almost a conditio sine qua non, of legal modernization as it is often portrayed. Law changed rapidly to meet new needs - or to steer the course of social transformation - at the same time and in the same way in those parts of the Western world in which private law was not codified, such as the common law world and Scandinavia. This leads a comparative legal historian to wonder whether there may be an explanation that unites the legal history of the regions in which other forms of normativity than codification prevailed - such as piecemeal statutes and regulations, or case law - with those that codified their private laws. How does the rise of regulatory law from the late nineteenth century onwards relate to this ${ }^{37}$

\footnotetext{
${ }^{35}$ Max Weber, Economy and Society: An Outline of Interpretive Sociology (Berkeley: The University of California Press, 1978), 865.

${ }^{36}$ Pio Caroni, Gesetz und Gesetzbuch: Beiträge zu einer Kodifikationsgeschichte (Basel: Helbing \& Lichtenhahn, 2003).

${ }^{37}$ See Regulatory Transformations: Rethinking Economy-Society Interactions, Bettina Lange, Thomas Dania, and Fiona Haines (eds.), (London: Hart Publishing, 2015).
} 


\section{The problem of periodization}

The third problem of the traditional scholarship is its concentration on the classical, nineteenthcentury codifications of private law. This problem is, obviously, also related to the Weberian conception of the nineteenth-century continental (French and German) law as the zenith of global legal development.

Weber himself, as stated above, draws a clear line between "pre-revolutionary" codes on one hand, and Code Civil and later codes on the other. In his highly influential History of Private Law in Europe, Franz Wieacker then follows this scheme, which then becomes the standard way to describe codification history. The true "codes" have been set apart from mere "compilations" of the earlier times (such as those of Hammurabi and Justinian, but also early modern law books such as the Danish Law of Realm of 1683 or the Swedish Law of the Realm of 1734). The reason to exclude the older ones is that they were not based on systematics developed by legal scholarship in the same way that the classical codifications were based on the Pandektenwissenschaft, and that the older ones did not claim exclusivity over other legal sources the way the classical codifications did.

However, older codes have also claimed exclusivity. Justinian's Corpus was already meant to be the only legal source, wiping out all others. The same was true for the Constitutions of Melfi, law promulgated in 1231 for the Kingdom of Sicily by Emperor Frederick II (check Abulafia, Nils Jansen). All major Nordic Codes also claimed exclusivity over other legal sources. Obviously, none of them succeeded in establishing themselves as exclusive legal sources. Jurists continued commenting on the law books both in Justinian's Byzantium, Frederick's Sicily, as well as in the Nordic countries. As time went by, new legislation also appeared everywhere. Courts developed their own practice.

However, the bourgeois codes did not succeed any better in establishing their exclusivity. Although Code Civil caused French legal scholarship to develop into what many perceived as a boring école d'éxegèse, the exegetical school solely involved in interpreting the Civil Code, towards the end of the nineteenth century the French legal scholarship was emerging creative and productive again. The German Civil Code established a strict principle of pacta sunt servanda, "promises shall be kept," which left no room for many legal institutions that the German gemeines Recht had entailed. 
The highest court of the Empire and the Weimar Republic, Reichsgericht, reintroduced many of them soon after the promulgation of the Civil Code in 1900. The best-known example is "Steam Price Case" (Dampfpreisfall), as a result of which the Reichsgericht-contra legem, against written law - again allowed for clausula rebus sic stantibus. With origins in medieval canon law, the clausula was an old ius commune institution of contract law. The clausula allowed to depart from a contract, if the circumstances prevalent at the time of the conclusion of the contract had drastically changed. This was the case in 1920, the German Reichsgericht decided the Steam Price Case. As a result of the after-war inflation, the price of steam had risen enormously. For the Court, this was sufficient reason for bypassing the original contract clause regarding the price. ${ }^{38}$

As to the systematizing tendency behind the nineteenth-century codifications, this is partly true. On the other hand, it is not far-fetched to say that at least the early modern codes were also based on particular systematizing conceptions (influence of Ramistic philosophy, the model of the Decalogue and so on).

V. The symbolic value of legal codes

The fourth problem of the traditional codification research has to do with its lacking attention to cultural contexts. Apart from purely legal objectives, legal codifications have always served as symbols. They have helped to highlight the genius of their authors or of the lawgivers, and codifications have helped to build national identities in much the same way as national anthems, national literature, or national borders.

Legal codes probably carried symbolic from quite early on. I will use Nordic medieval legislation to illustrate this. In Sweden (as in Denmark and Norway too), legislation began at the provincial level. Nine Swedish provincial laws provincial laws still exist in manuscripts either partly (the chapter on the church of the law of Småland) or as a whole. These include he provincial laws of West Gothia (Västergötland), East Gothia (Östgötalagen), Småland (Smålandslagen), Gotland (Gutalagen), Uppland (Upplandslagen), Hälsingland (Hälsingelagen), Södermanland (Södermannalagen), Dalarna (Dalalagen), and Västmanland (Västmannalagen). It remains unclear when the first versions of the provincial laws were compiled, but the oldest, the Law of Western Gothia, probably

\footnotetext{
${ }^{38}$ See Klaus Luig, "Die Kontinuität allegemeiner Rechtsgrundsätze: Das Beispiel der clausula rebus sic stantibus," in Rechtsgeschichte und Privatrechtsdogmatik, Reinhard Zimmermann, Rolf Knütel, Jens Peter Meincke (eds.), München: C. F. Müller, 1999, 175-179.
} 
dates to the 1220s. Some provincial laws are private compilations, while two of the Swedish provincial laws have a royal confirmation: the Law of Uppland (1296) and the Law of Södermanland (1327). ${ }^{39}$

Since provincial codes were so numerous, one might think that written law governed medieval Swedish society. This is, however, probably quite far from the truth. Law manuscripts were dear, and it is difficult to estimate how many courts of law even possessed a copy of the local provincial law. Anyway, most court members would not have been able to read. Medieval written laws, then, probably mirrored legal practice, but they hardly directed it. It is much more reasonable to assume that legal practice led the way. Jürgen Weitzel and Pia Letto-Vanamo have emphasized consensual decision-making as crucially important in medieval peasant communities, in which central power was weak. ${ }^{40}$ When peasant communities gradually, during the early modern period, lost part of their control of the local courts, the importance of written law in the everyday legal affairs possibly grew. This story, however, must remain outside the limits of this study.

If legal practice was more important than written law, why codify at all? This is where come to the symbolic function of the codes. Fernanda Pirie has suggested laws are not always primarily instruments of government at all. Instead, she claims that "we must pay attention to their ideological and symbolic aspects." Pirie's examples are from early medieval Europe and Tibet. According to Patrick Wormald, the Germanic laws were also attempts to impose Roman civilitas upon uncivilized barbarians. Germanic rulers - and later Charlemagne - saw themselves as followers of Roman emperors, whose primary tasks had included making laws. Therefore, medieval laws were in Latin and some of them - the Visigothic law is an example, were divided into 12 books, following the Law of the Twelve Tables. ${ }^{41}$ According to Pirie, early medieval Germanic laws (including the Frankish Lex Salica, the Burgundian, Visigothic, Lombard and Anglo-Saxon codes) consisted of "records of custom, statements of policy and records of judgments in a haphazard order." ${ }^{42}$ Pirie refers also to Geoffrey MacCormack's studies on the legal history of China, where a clear continuation developed between the codes of the different dynasties. The code of the Tang dynasty (from the seventh to the tenth centuries) remained unchanged for until the late thirteenth-

\footnotetext{
${ }^{39}$ Dietmar Strauch, Mittelalterliches nordisches Recht bis ca. 1500: eine Quellenkunde (Berlin: de Gruyter, 2016); Korpiola, "High and Late Medieval Scandinavia".

${ }^{40}$ Jürgen Weitzel, Dinggennossenschaft und Recht: Untersuchungen zum Rechtsverständnis im fränkisch-deutschem Mittelalter (Köln: Böhlau,1985); Pia Letto-Vanamo, Käräjäyhteisön oikeus: oikeudenkäyttö Ruotsi-Suomessa ennen valtiollisen riidanratkaisun vakiintumista (Helsingin: Helsingin yliopisto, 1995).

${ }^{41}$ Patrick Wormald, Legal Culture in the Early Medieval West (London: The Hambledon Press, 1998), 21-38.

${ }^{42}$ Fernanda Pirie, "Law before the Government: Ideology and Aspiration," Oxford Journal of Legal Studies 30:2 (2010): 207-228.
} 
century Sung dynasty. Many of the provisions of the Tang code then passed via Ming and Qing codes all the way to the twentieth century. Evidence shows that large parts of the codes were never applied in practice. ${ }^{43}$ Similarly in Tibet, the Code of the Fifth Dalai Lama from the mid.seventeenth century remained unchanged until the twentieth century. Sumptuously produced copies were kept out of laymen's reach and sometimes ceremoniously consulted by judges. ${ }^{44}$ Pirie's argument is that none of these laws - either Germanic, Chinese, or Tibetan - were practical instruments of government or justice. Instead, they represented governments with religious foundations or antecedents in great imperial civilizations. The actual legal disputes were resolved through other means, with a symbolic reference to the codes, at the most. ${ }^{45}$

It is probably not an exaggeration to say that the symbolic value of codes has been present always. The French Civil Code is an excellent example of this. Napoleon himself is famously reported to have said that Code was his finest accomplishment. The cultural prestige that the Civil Code is reflected in Stendhal's statement, according to which he read a passage of the Code every evening to keep his language in shape. In addition, of course, the Code's spreading to a huge amount of countries from Portugal to Paraguay cannot only be explained by French political dominance or the Code's superb legal qualities, but largely by the sheer prestige that its adoption brought even to foreign legislators. The hitherto failed attempts at creating a civil code for the European Union, which is desperately lacking well-working unified symbols, attests to the great symbolic power of the codes.

However, it would be a mistake to dismiss all codes as mere symbols of political power or cultural progress. Situations vary from another, and this can already be seen in the middle ages. Some codes were, besides whatever symbolic value they might have carried, also instrument of governance. In the twelfth and thirteenth centuries, the canon law of the Catholic Church expanded rapidly. A major instrument of ecclesiastic regulation were papal bulls and decretals, in addition to which synods produced normative material as well. From early on, these laws were compiled. At first this occurred through private initiative, an example of which are the three collections of Ivo of Chartres around 1100 (Tripartita, Decretum, Panormia). Eventually, the Church took control of the collections and produced works such Liber Extra (1234). It is fair to assume that already the first compilations arose out of practical demand. This was the case certainly even more when the sheer

\footnotetext{
${ }^{43}$ Geoffrey MacCormack, Traditional Chinese Penal Law (Edinburgh: Edinburgh University Press, 1990).

${ }^{44}$ Dieter Schuh, "Recht und Gesetz in Tibet" in L Ligeti (ed), Tibetan and Buddhist Studies Commemorating the 200th Anniversary of the Birth of Alexander Csöma de Körös (Akadémiai Kindó: Budapest 1984), 38-39 (cited here through Pirie 2010); Fernanda Pirie, Peace and Conflict in Ladakh: The Construction of a Fragile Web of Order (Brill, Leiden 2007); and Dawa Norbu, Red Star over Tibet (Collins, London 1974) (cited here through Pirie 2010).

${ }^{45}$ Pirie, "Law before the Government," 215.
} 
amount of papal decretals skyrocketed. The Church, if anything, was a global community governed by law - "the first modern state" as Harold Berman aptly called it - and collections of law greatly helped in governing it.

It is well known that the church legislation attracted a true wave of putting customary law into writing all over Europe. Examples include the Saxon Mirror, Coutumes de Beauvaisis, and Siete Partidas, all from the thirteenth century. The example of church legislation was certainly an important factor in the background of Swedish medieval codes, not the least because leading local churchmen, together with native strongmen, were actively involved in the codification processes. However, it seems reasonable to presume that an important reason for codification of Swedish laws was to underline the role of both the church and the community leaders as cultural and political leaders.

A decisive turning point when codes definitely began to serve primarily other than symbolic functions was the nineteenth century. This was the century, when legal positivism was developed on the European continent. Written law now became the supreme source of law, and in most countries, codes represented written law par excellence. Even though, as said, especially civil laws had important symbolic functions as prime representatives of national legal unity, they were certainly not symbols only. From the point of view of the power holders, codes were instruments of governance, and for legal practice, they were everyday work tools.

\section{Conclusion: codifying contemporary law}

Legal codes have served multiple purposes. From early on, they have served as symbols of power, drawing their legitimacy from ancient roots. When observed historically, the practical importance of the codes has often been meagre. Although the symbolic significance of the codes has never disappeared, from the nineteenth century onwards their importance for practical legal life has been undisputable. Nevertheless, I hope to have been able to show that the traditional view of looking at the codification history through the lenses of nineteenth-century history of continental law is in many ways misleading and in need of revision.

My interest in the historical developments described above is, however, far from antiquarian. Although I firmly believe in the importance of legal historical research as such, some historical studies directly relate to modern problems. The problem of codification is one of those, as forms of 
normativity continuously emerge on modern discussions on law and legal development. The European Civil Code has been a standard topic for the past two decades, and the discussion seems not to have ceased even despite the political chances of the code seem scarce. Other international instruments of civil law (UNCITRAL, CISG, Draft Common Law of Reference) are high up on the agenda, whenever international commercial law is debated. The debates often concern the relation of these codifying efforts to transnational law - be it of a free-floating kind, created by international merchants such as banks, or created by international organizations.

In order to come to grips what is happening today and what may happen tomorrow, we should attempt better to understand the changing forms of normativity from the seventeenth century until today. Phenomena such as the substitution of statute law for religious and moral normativity, codification and non-codification, and transnational law and soft law should receive special attention. They should be understood as a whole. The cultural, political, and religious context of the different forms of law and normativity, and the impact of law on culture, politics, and religion should be of vital significance to future research.

Many interesting questions need answers, which I have not been able to provide in this short piece. Fors instance, the following problems emerge: How did the early modern European codes differ from the nineteenth-century codifications? Why did some countries not codify their laws, while most did? How does the problem of different forms of normativity relate to legal modernization? Can we speak of a "rise and fall" of the codification? We should place the traditional story of codification based on European core countries into a larger picture of different normativities and into a comparative framework of larger Western and global context. Doing this, the existing Stand der Lehre on codification would probably be thoroughly revised, as it remains based on an antiquated conception of European legal history as the history of European core areas only, and on the nineteenth-century codifications as the center of scholarly attention and motor of modernization.

Recommended reading:

Klaus Peter Berger, The Creeping Codification of the New Lex Mercatoria (London: Springer, 1999)

Harold Berman, Law and Revolution: The Formation of the Western Legal Tradition (Cambridge, Mass.: Harvard University Press, 1983).

Harold Berman, Law and Revolution: The Impact of the Protestant Reformations on the Western Legal Tradition Tradition (Cambridge, Mass.: Harvard University Press, 2006). 
Pio Caroni, Gesetz und Gesetzbuch: Beiträge zu einer Kodifikationsgeschichte (Basel: Helbing \& Lichtenhahn, 2003)

Jean-Louis Halpérin, Five Legal Revolutions since the $17^{\text {th }}$ Century: An Analysis of a Global Legal History (Cham: Springer 2014).

Sten Gagnér, Studien zur Ideengeschichte der Gesetzgebung (Stockholm: Almquist \& Wiksell, 1960)

William Twining, General Jurisprudence: Understanding Law from a Global Perspective (Cambridge: Cambridge University Press, 2009)

Patrick Wormald, Legal Culture in the Early Medieval West (London: The Hambledon Press, 1998) 